Article

\title{
Living and Planning on the Edge: Unravelling Conflict and Claim-Making in Peri-Urban Lahore, Pakistan
}

\author{
Helena Cermeño \\ Institute for Urban Development, Department of Urban Sociology, University of Kassel, 34127 Kassel, Germany; \\ E-Mail: hcermeno@asl.uni-kassel.de
}

Submitted: 17 November 2020 | Accepted: 10 February 2021 | Published: 25 May 2021

\begin{abstract}
In Lahore, Pakistan's second largest city, high population growth rates, decades of rural-urban migration, and rampant land and real-estate speculation have contributed to the rapid urbanization of peri-urban land and the engulfing of pre-existing rural settlements. Lahore's spatial transformation goes hand in hand with an increasingly complex urban governance framework. Historically shaped by colonial planning institutions and decades of political instability as power alternated between military and civilian regimes, Pakistan's governance practices have contributed to increasing levels of urban segregation and inequality. This raises questions around the in- and exclusionary role of planning in fostering or constraining residents access to housing and services. Comparing three vignettes and drawing upon insights gained from extensive fieldwork, this article employs the concept of 'access-assemblages' to analyze how access to urban resources-i.e., land, housing, and services-is experienced, disputed, and negotiated in the rapidly urbanizing peri-urban fringe of Lahore. The cases represent different spatial and socio-political configurations brought about by a variety of actors involved in the planning and development of the city's periphery as well as in contesting development: private developers, the army, the city development authorities, and the residents of affected villages. The analysis unpacks the planning rationalities and mechanisms that reinforce inequalities of access and exclusions. Unfolding practices that enable or hinder actors' ability to access resources sheds light on the complex layers assembled in urban planning in Lahore and serves as a basis to rethink planning towards a more inclusive approach.
\end{abstract}

\section{Keywords}

access-assemblages; access theory; assemblage; claim-making; housing; land dispossession; peri-urbanization; qabza; urban governance; urban politics

Issue

This article is part of the issue "Planning for Rapid Change in Cities" edited by Karina Landman (University of Pretoria, South Africa).

(C) 2021 by the author; licensee Cogitatio (Lisbon, Portugal). This article is licensed under a Creative Commons Attribution 4.0 International License (CC BY).

\section{Introduction}

The southern fringe of Lahore-the capital of Pakistan's largest province, Punjab, and country's second largest city with an estimated population of 11.13 millionhas been rapidly urbanizing over the last four decades (Javed \& Riaz, 2020). Nearly thirty years ago, a conflict took place between the Pakistan army and the residents of Charrar Pind-a formerly rural settlement now well within the urban sprawl. The agricultural lands surrounding the village were progressively sold and trans- formed, as housing projects-locally referred to as housing schemes-were rolled out by the army. Today, the village stands within the Defence Housing Authority (DHA) that serves as modern housing for the affluent classes. Well beyond Charrar Pind, in the southern margins of the city, newly planned housing schemes continue to spring up across what was previously rural hinterland, replacing pre-existing villages. In the past, urban expansion in the northern and western peripheries had been contained by the river Ravi. But in August 2020, Prime Minister Imran Khan launched the Ravi Riverfront Urban 
Development Project (RRUDP), an ambitious undertaking that plans to displace residents of the villages along this periphery as well.

Against this backdrop, this article analyzes processes of land appropriation at the peripheries of Lahore and discusses how they affect and are contested or negotiated by local communities. To do that, the article explores urban developers' practices as well as strategies of resistance and negotiation employed by residents of the affected villages. The article uses three ethnographic vignettes to illustrate its analysis of disputes over peri-urban land and their entanglements with different governance actors and planning institutions. These exemplify the ongoing spatial restructuring in the periphery of Lahore and indicate the main actors involved, namely Bahria Town, Pakistan's most powerful private developer; the army's DHA; and the Lahore Development Authority (LDA), a provincial government institution. Through these examples, the article seeks to understand how different actors shape their claims over land, housing, and services, as they enter complex and contentious relationships. For this purpose, the article develops the concept of 'access-assemblages.'

By coupling two different theoretical strands, access theory (Ribot \& Peluso, 2003) and agencement/ assemblage perspectives (Deleuze \& Guattari, 1987), an access-assemblages framework allows the exploration of changes in access to urban resources at Lahore's fringes -in this case, access to peri-urban land, housing, and services. It examines how these are experienced, disputed and negotiated, within complex configurations of actors and institutions. The article argues that an accessassemblages frame is fruitful for exploring the in- and exclusionary role of planning, i.e., to what extent current planning practices influence the ability of local populations to benefit from the restructuring of the landscapes they inhabit. In doing so, the article contributes to the body of literature on land transformations and dispossessions in rapidly urbanizing cities. From a theoretical perspective the article seeks to draw attention on the possibilities of access theory for the scholarship of urban planning and to contribute to the expansion of perspectives in assemblage-thinking.

\section{Land Appropriation and Dispossessions}

As in other major Pakistani cities, Lahore has seen a massive expansion of its real estate market since the 1990s (Javed \& Riaz, 2020). This is visible in the ongoing transformation of large swathes of agricultural land (Zaman \& Baloch, 2011). However, the rapid development of the urban fringe has not necessarily translated into improved housing access for low-income populations. Instead, the dominant processes of urban development are characterized by exclusionary urban visions, low levels of colonization in housing schemes (Anjum \& Hameed, 2007), and displacement of local communities. The resulting extensions of vacant plots and scattered housing societies-many of which as gated communities - have attracted land speculation and benefited the upper-middle classes. Pakistan in this respect is not an exceptional case. The growing literature on peri-urbanization in the Global South describes similar processes of exclusion (Nygren \& Quesada, 2020), 'regimes of dispossession' (Levien, 2015), and the challenges to urban planning posed by the proliferation of gated communities (Bagaeen \& Uduku, 2010; Landman, 2004). In the Pakistani context, some new work emphasizes the role of secluded residential enclaves in providing relatively safe spaces (Bint-e-Waheed \& Nadeem, 2019), but other studies criticize the resulting fragmentation of the city (Gul, Nawaz, Basheer, Tariq, \& Shah, 2018). Mallick (2018) goes even further by considering these enclosed housing schemes in particular, and the restructuring of space in Pakistani cities in general, as representative of an emerging material and even ideological project which mediates the aspirations of the emergent upper-middle class through (exclusionary) claims over urbanity and modernity. Those claims are then instrumentalized by land developers for the legitimation of their 'secure' housing societies. Against this pursuit of security, the processes underlying the development of such residential enclaves often involve the use of force or the threat of violence by powerful private or state institutions (Khan, Akhtar, \& Bodla, 2014; Levien, 2015). This is well captured by the local idiom of 'qabza' (Ewing, 2012).

Qabza is the act of taking possession of a specific site and might be translated as seizing, occupying, or trespassing (Ewing, 2012). The concept can refer to landgrabbing in urban development processes (Hull, 2012), or taking control of specific buildings such as mosques (Khan, 2012), but it can also be seen, as Ewing (2012, p. 534) puts it, as a metaphor of "how things operate" in a wide range of domains in the Pakistani context. The growing visibility of qabza manifests the importance of illicit mechanisms in processes of land appropriation and demands a reconsideration of classic analyses of dispossession. Often, scholars have discussed the displacement of local communities and the transformation of agricultural land as an example of what Marx called 'primitive accumulation,' or Harvey (2004), in a more recent formulation, refers to as 'accumulation by dispossession.' From a primitive accumulation perspective, however, land dispossession is a precondition for capitalist development, and not a result of it. And where Harvey's notion of accumulation by dispossession does recognize diverse contemporary dispossessions as a result of capital accumulation, the role of financial capital is often overemphasized in this analysis. Both concepts, then, overlook the deeply political processes embedded in practices of land transformation that include both coercive force from above-often exercised by the state itself (Levien, 2015)-and strategies from below. The latter have been often conceptualized through the lenses of 'political society' (Chatterjee, 2004)-spaces of everyday subaltern strategies-and the 'quiet encroachments 
of the ordinary [people]' (Bayat, 2013), and, more specifically in the Pakistani context, as contestations through moral claim-making to negotiate the right to stay (Rizvi, 2019). There are, however, also studies of farmers' smallscale encroachments on village communal lands in neighboring Indian Punjab, that show how 'political society' characterized here by ad hoc informal arrangements enabling land-grabs (or qabza from below) and their inherent partisan clientelism bargains - can also be complicit in processes of dispossession (Martin, 2019, p. 241). These findings posit that access to land (via land appropriation, land grabbing, or qabza) is not only an area for conflict and contestation, but also for negotiation and cooperation that involves different actors and institutions operating at different scales.

Qabza-seen as modes of operating beyond established boundaries-is facilitated by the complexity of an urban governance framework in which planning visions, mandates, and jurisdictional borders are increasingly blurred. Overlaps between urban governance institutions and holdovers from the colonial era contribute to the failure of planning tools (Hameed \& Nadeem, 2008). The alternation of civilian and military governments at the national level and recurrent changes in local government regulations have further hampered local governance and reinforced the role of the army. Two cantonment boards (civic administration bodies under the Ministry of Defence) as well as the army-administered DHA-with its own rules and regulations-mirror the urban governance structures of 'civilian Lahore.' They further distort the already unclear jurisdictional boundaries of the city. Planning perspectives pursuing modernization have, on the other hand, oversimplified urban realities, and facilitated the primacy of the private sector. As result of colonial legacies, frequent changes in governance structures, and emergent trends in international planning, Lahore's urban governance framework has produced the conditions for legal and spatial zones of exception and ambiguity in which different actors and institutions operate with differentiated levels of power and influence.

\section{Access-Assemblages}

Multiple theorists have developed assemblage-thinking approaches for a variety of analytical purposes (DeLanda, 2006, 2016; Deleuze \& Guattari, 1987). Although there is a growing disagreement over how to theorize and operationalize assemblages (see sections in City 2011, Vol. 15, Issues 2-6, and sub|urban-Debatte 2014, Vol. 2, Issue 1 ), in this article I read through selected concepts from Deleuze and Guattari's (1987) writings on the notion of agencement/assemblage (i.e., 'emergence,' 'deterritorialization/reterritorialization'). The concept of assemblage is useful in describing the multi-layer, multiscalar, dynamic, and unstable webs that are created by actors and institutions involved in processes of land appropriation and dispossession in Lahore. In these webs, the liaisons between the constitutive elements are constantly being (re)shaped. This illustrates the importance of 'becoming' that Deleuze and Guattari underscore when they ask what kind of assemblage would be required to produce a given situation (Buchanan, 2021). Investigating the dynamic configuration and relations of these assemblages is crucial to an understanding of how urban development practices operate. More, an assemblage-thinking perspective acknowledges the various scales in which nested assemblages function (e.g., from interpersonal relations to institutions, organizations, neighborhoods, cities, states, and so on) and offers an analytical approach to understanding the processes through which assemblages 'emerge' (what Deleuze \& Guattari [1987] term de/reterritorialization). Assemblages perspectives have been faulted, however, for insufficiently describing underlying power relations. Although they increasingly give attention to the notion of power (Allen \& Cochrane, 2010; McFarlane, 2009; Russell, Pusey, \& Chatterton, 2011), its operationalization often remains elusive. This article argues that access theory (Peluso \& Ribot, 2020; Ribot \& Peluso, 2003) offers here a valuable conceptual supplement.

Access theory is particularly relevant in the study of governance practices that operate in liminal spaces between the formal and the informal (Dovey, 2012). Ethnographic studies in the Global South and postcolonial contexts report situations in which formal recognition of claims and resulting property rights do not preclude the outcomes they are designed to protect against, such as conditions of landlessness, displacement, marginalization, and poverty (Gilbert, 2002). This implies that property rights alone are no guarantee of secure access to resources, as there are 'gray zones' in which people do have rights but cannot benefit from resources and vice-versa, when access is not necessarily linked to property or sanctioned by legal regimes of rights (Sikor \& Lund, 2009). The concepts of 'gray zones' or 'zones of exception' (Roy, 2011) emphasize this liminal space in urban governance. It is in this liminal space that the notion of qabza operates-where "power and networks prevail over property rights and the rule of law" (Ewing, 2012, p. 535).

By expanding the classical notion of rights, access theory provides an analytical framework for exploring practices and mechanisms that enable or constrain "the ability [of actors] to derive benefits from things" (Ribot \& Peluso, 2003, p. 153). 'Access mechanisms' assembled in 'webs of access' determine the capacity of actors to gain (process by which access is established), control (to mediate other's access to resources), or maintain access (by expending resources or powers). Access mechanisms encompass a wide range of possibilities, including 'rights-based' (legal and illegal access) or 'structural and relational' mechanisms (i.e., access to technology, capital, markets, labor opportunities, authority, social identity, and relationships). The underlying power relations, referred to as 'bundles of powers,' are 
key to understanding how the distribution of benefits operate-in our case, access to peri-urban land, housing, and services. While access theory has been widely used in the scholarship on (natural) resource management, it has less currency within the field of urban planning. This article argues that an access approach is a powerful theoretical tool and a compelling guide for empirical analysis. 'Access-mapping' can facilitate a systematic exploration of processes of change, claims-making, and urban contestations by tracking: 1) the flow of resources and distribution of benefits, i.e., the ability to gain, control, and maintain access; and 2) the underlying mechanisms and power relationships fostering or constraining such an ability.

By combining the two theoretical strands under the concept of access-assemblages, this article shows how the exploration of the power relations and access mechanisms implicated in assemblages of actors and institutions elucidates the in- and exclusionary role of planning. This assumes that power relations largely determine the ability of developers and villagers to benefit from urbanization processes. In turn, selected concepts from assemblage theory sharpen the concept of webs of access by investigating the conditions under which these webs come into being. The article draws particularly on the concepts of emergence and deterritorialization/reterritorialization. Territorialization refers to the sharpening of the spatial boundaries of a given social or spatial assemblage, e.g., a community of people, an organization, or a neighborhood (DeLanda, 2006). In this way, territorialization leads to the (temporary) stabilization of a given assemblage into a particular formfor instance, through jurisdictions, or socio-spatial segregation. On the other hand, processes which either destabilize spatial boundaries or increase internal heterogeneity are described as 'deterritorializing' (DeLanda, 2006 , p. 13). From Buchanan's (2021, p. 102) perspective, deterritorialization entails functioning without a territory, a sort of "freefalling into chaos without a safety net or harness". For this reason, opportunities to reterritorialize are immediately sought. Hence, assemblages move between deterritorialization (unmaking) and reterritorialization (making) as they constantly become. For Deleuze and Guattari, it is in this state of chaos and disorder that 'desire' - a key notion in their writings but often neglected in works that draw upon them-takes place and becomes productive (Buchanan, 2021). This functions along 'lines of flight'-paths of 'rhizomatic' deterritorialization (Deleuze \& Guattari, 1987, p. 508). These can open new possibilities, e.g., liminal spaces of opportunity, deregulation, and zones of exception; create alternative paths; or lead to a whole new assemblage (Dalton, 2019). Access-assemblages can therefore be described on the basis of two main dimensions: the first is emergence, the inherent capacity of assemblages to de/re-territorialize. The second dimension represents the connections between components of the assemblage characterized by material actions or expressive signifiers. These include access mechanisms-that are rights-based, structural, and relational-and their underlying power relations.

\section{Conflicts over Access to Land, Housing, and Services}

\subsection{Methodology}

This section presents three cases, examples of both ongoing processes of urbanization in Lahore's peri-urban areas as well as the ways these processes are contested. The vignettes show the main actors and institutions involved, i.e., Bahria Town, the DHA, the LDA, and the residents of villages affected by the land transformation (see Figure 1). To explore how access to urban resources i.e., land, housing, and services, is shaped, disputed, and negotiated, the article draws on the notion of access-assemblage by asking: What sort of assemblage would be required to create these particular access dynamics? Inspired by Baker and McGuirk (2017), accessassemblages are operationalized in two steps, guided by the questions 'Where to look?' and 'What to look at?': First, tracing sites and situations, and second, revealing emergence and access mechanisms. The first step is concerned with identifying relevant sites, such as administrative territories, organizations, regulations, communities, or consultancy firms, and situations such as conflict, cooperation, discourses, or dominant notions of development and modernity. The second step is concerned with access-mapping, which includes exploring: a) the flow of resources and distribution of benefits; and b) how this operates, that is, which access-mechanisms and underlying power relations can be identified. In step one, the focus is primarily on urban developers and on identifying the practices from above that have triggered contentious situations with residents of villages at the boundary. In step two, the focus is largely on practices from below as villagers articulate claims in relation to their disputes with urban developers.

The case studies are based on ethnographic fieldwork conducted during several research stays in Lahore between November 2014 and March 2016. Most of the empirical data for the three cases presented here was gathered from October to December 2015 and in March 2016. The same methods were applied in all three cases. Qualitative research included informal and in-depth interviews (In total 33: 11 in Bahria, 17 in DHA, and 5 in LDA/RRUDP) with residents of rural villages and housing schemes, real-estate agents, and local representatives. Of the urban development agencies, it was only possible to interview LDA officers. Some informal interviews were combined with participant observation as 'go-alongs' (on foot and by car; Kusenbach, 2003). Due to the sensitivity of the information, interviews were not recorded; instead, extensive fieldnotes were produced. The analysis also draws on documentary materials. These include local newspaper reports that covered the contentions over the land, real-estate maps, 


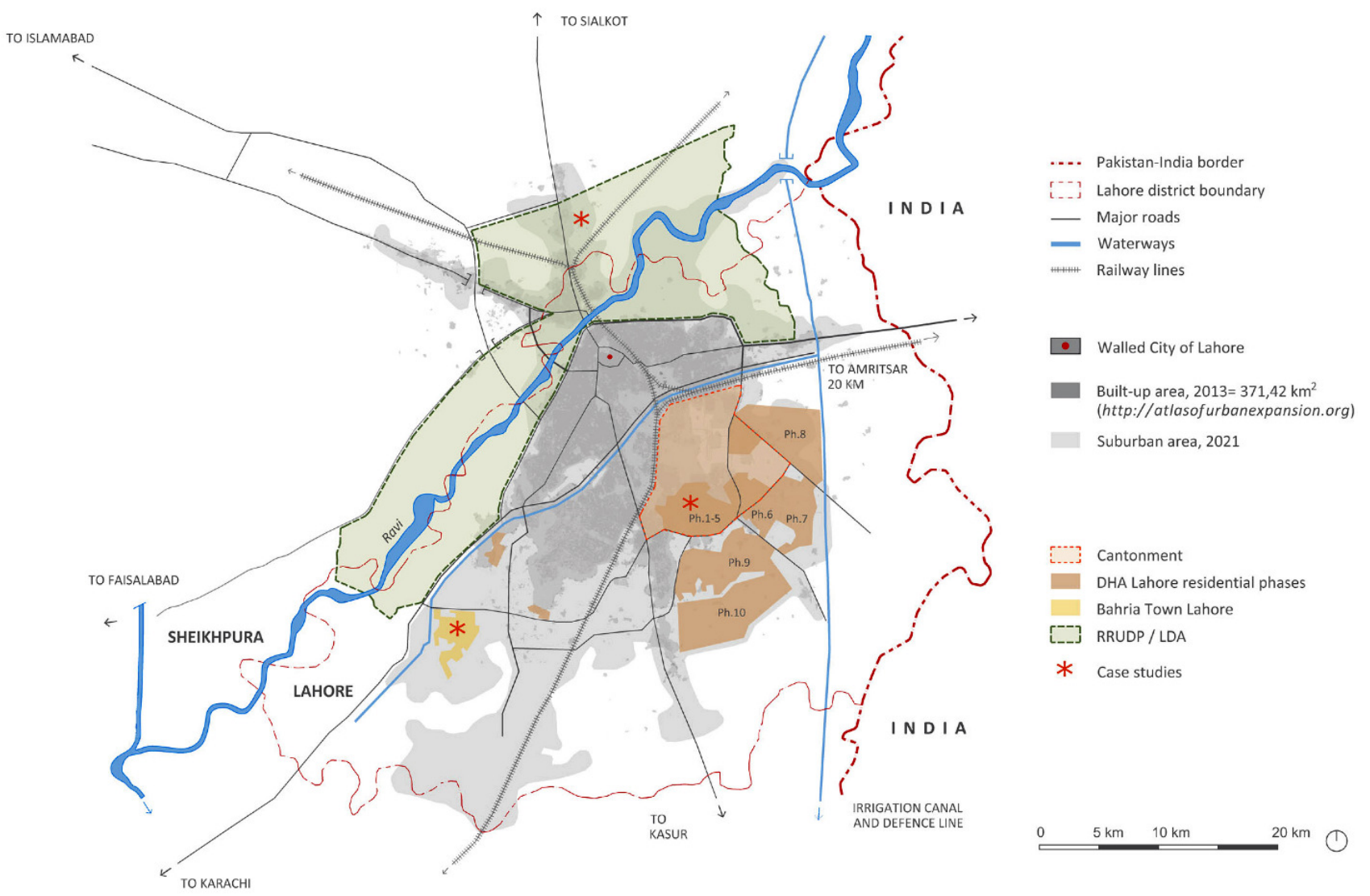

Figure 1. Map of Lahore and location of the three selected case studies.

the 2015 drafts of the RRUDP Strategic Development Plan (SDP) and Feasibility Reports, as well as the transcript and translation of the Prime Minister's speech at the RRUDP launching ceremony on September 15, 2020. These materials were treated as ethnographic artefacts, manifesting ways of thinking and acting with traceable itineraries and effects.

\subsection{CASE I: Bahria Town-(In)Security of an Exclusionary Gated Community}

Over the last twenty years, the housing project of Bahria Town Lahore has expanded its territory across the city's southern periphery, displacing pre-existing villages. With an area of about $16 \mathrm{~km}^{2}$, the housing scheme is today a consolidated gated community. Its perceived security and high development standards have contributed to its growing reputation (see Figure 2). Different strategies have made the housing scheme appealing for middle and upper-class residents and investors: It offers a wide range of plot sizes, pitching exclusionary housing to the emergent middle-classes, and it employs 'world-class' marketing, which mobilizes an eclectic collection of foreign imaginaries-including a built reproduction of the Eifel Tower as seen in Figure 3 (fieldnotes, November 10, 2015). But residents from a village next to Bahria Town still recall the violence through which the housing scheme came into being. Their accounts described how the private developer coerced families who owned agricultural land into selling their properties at rates well below market prices (interviews, March 18, 2015). They also described (illegal) rights-based mechanisms deployed in collusion with local patwaris and tehsildarslow level bureaucrats in charge of land records-as well as relational mechanisms such as co-optation, intimidation, and use of force by the developers themselves or through their intermediates (qabza groups, police, military, and land authorities) to gain access to the land (interviews, November 1-10, 2015, and March 20, 2016). These accounts from Lahore mirrored narratives about the violent conflicts in the other developed Bahria Towns in Rawalpindi (another major city, $400 \mathrm{kms}$ north of Lahore in Punjab; Khan et al., 2014) and in Karachi (Zaman \& Syed, 2016). At first, press reports voicing the claims of disenfranchised villagers were repressed by the developer's networks of association with the media, and high-level military officials and bureaucrats. However, the large number of court cases progressively increased the visibility of the illicit activities involved in the development of the Bahria Town housing schemes (Syed, 2019).

The ability of villagers to maintain possession of their land was constrained by the violent processes through which Bahria Town Lahore emerged. Though villagers deployed strategies of resistance, such as social mobilization, small protest rallies and court cases, these were not sufficient to preserve their control over the 


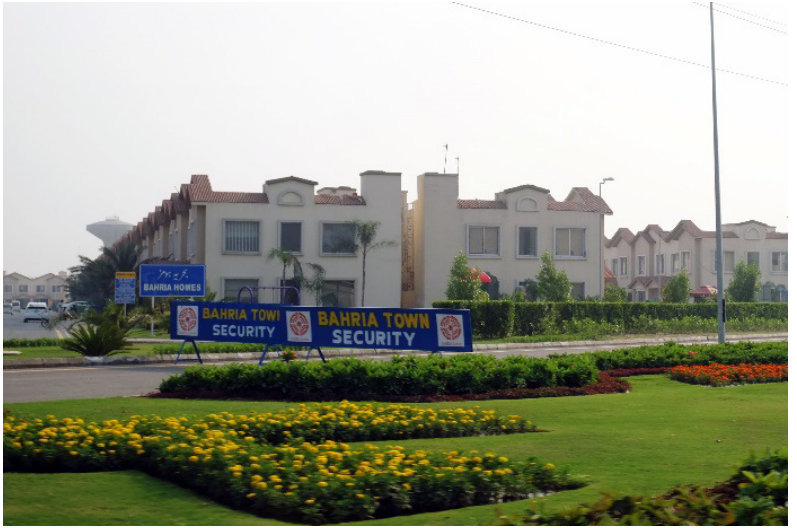

Figure 2. Security checkpoint within Bahria Town Lahore, 2015.

land (interviews, November 1-10, 2015, and March 20, 2016). Ultimately, villagers were either displaced to settlements on the borders of the gated-community or moved elsewhere. Today, while residents within the territorial boundaries of Bahria Town enjoy high standards of housing and services, the exclusion of neighboring villages manifests in low quality construction and service provision. Despite these differences, for the most part, narratives of conflict and resistance have turned into narratives of cooperation over time. This is a result of linkages between Bahria Town and the neighboring settlements characterized by flows of labor and capital, as well as mutual dependencies. Although some villagers shared concerns about losing their traditional lands in the process of urbanization, most emphasized the perceived benefits from living close to the high-income residential enclave, such as social status, economic gains, and access to employment opportunities within and around Bahria-as exemplified by strategically developed markets at the edge of the settlements. Similarly, some villagers benefited from improved access to healthcare-contingent on employment in Bahria Town. Others make speculative calculations over the potential gain from selling their remaining agricultural land, as they express aspirations to move to Bahria Town (interviews, November 2, 2015, and March 18, 2016). On the other hand, however, Bahria Town's upper- and middle-class residents tend to view the villagers through the tropes of poverty, criminality, and backwardness as they make exclusionary claims over urbanity and modernity (interviews/fieldnotes: March 19-20, 2016).

The emergence and de/reterritorialization of Bahria Town over the years evidences the unequal power relationships between the private developer and residents of pre-existing villages, who ultimately lost access to, and control over, their property. The bundles of power and access mechanisms-mostly illicit and relational based-deployed by the private developer outpowered those of the villagers, despite their (legal) rights-based, affective, and moral claims to the land. The mecha-

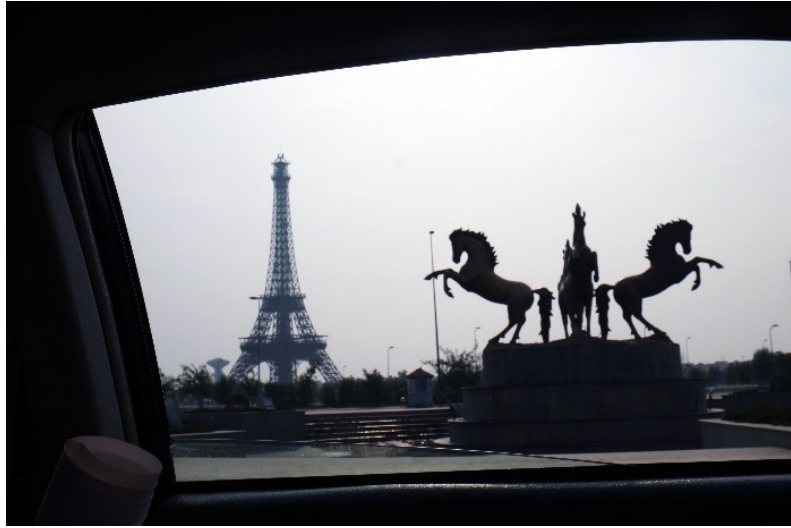

Figure 3. Bahria Town Lahore world-class style and foreign imaginaries. Photograph taken during a ride-along with a real-estate broker, 2015.

nisms (to gain, control, and maintain access) that were deployed on both sides of the land contention deterritorialized spatial and social boundaries. The subsequent reterritorialization processes, facilitated by the marketing strategies of Bahria, its reputation among the affluent classes, its unaffordability to low-income populations, and its surrounding wall-a physical barrier between different lifeworlds-have sharpened the socio-spatial boundaries between the housing scheme and the surrounding settlements. Bahria Town Lahore exemplifies a highly exclusionary process of urban planning that has constrained the ability of local communities, and low-income villagers in particular, to benefit from improved housing and service provision. However, the porosity of the border between Bahria Town and neighboring villages can be understood as a potential 'line of flight,' a path for renewed deterritorialization and opening of possibilities. In addition to already perceived benefits experienced by villagers, i.e., social status and access to capital and labor, many are attracted to the lifestyle and standard of life represented by Bahria. Desire for development, or as Tania Murray Li (2007) puts it, the "will to improve," is in this case articulated from below, and could serve in Deleuzian terms as a trigger for deterritorialization and the articulation of further claims.

\subsection{CASE II: DHA and the Confined (Rural) Communities}

Housing schemes developed by the DHA are considered modern and exclusive. Their popularity is linked to their high quality, but also to the hegemonic position of the military in Pakistani society. The Pakistani military has accumulated economic and political power over recurrent periods of military rule (1958-1969, 1977-1988, and 1999-2008) by lobbying civilian governments in policy and budget allocations (Khan et al., 2014) and through its increasing corporatization, including a booming real-estate business (Siddiqa, 2007). The role of the military in land transformation can be traced back to 
1947 Partition and the allotment of evacuee land to military officers immigrating from India (Nawaz, 2008). The involvement of the army in land acquisition, allocations, and distribution positioned officers in privileged positions to set the path for their prospective housing schemes. Army real-estate expanded in the 1980s under General Zia Ul-haq, intensified after 1999 under General Pervez Musharraf's military rule, and continues in full swing today despite the return to civilian rule. The Land Acquisition Act 1894 has been a key element in this expansion, enabling the military to acquire land for 'public purposes' with meagre compensation to private owners or other state institutions. Besides the lax interpretation of the public purpose category-which is translated to include the commodification of state land for the benefit of high-ranking officers-examples of land grabs and irregular land conversions (e.g., former military training grounds turned into exclusionary facilities) have been widely reported (Siddiqa, 2007). It was within this framework that the DHA Lahore came into being as a development authority under military federal control. This happened in 2002 when the army took over the former Lahore Cantonment Cooperative Housing Society (Babar, 2019). DHA's housing schemes have thence emerged and developed independent of, and unaccountable to the civilian government institutions. Today, its holdings cover more than $150 \mathrm{~km}^{2}$ in eleven phases across Lahore as extensions to the original military Cantonment in the city's south-east periphery (Javed \& Riaz, 2020). DHA's sprawl has acquired such dimensions that there is a widespread perception that at least one third of the city is army-controlled land (interviews, March 10, 2016). Inevitably, this expansion has displaced numerous local communities.

Local communities in the south-east boundary of Lahore have been engaged in the contention over the land for at least three decades. This is well illustrated by Charrar Pind's settlement. The village stands surrounded by DHA's residential phases 1 to 5 (see Figures 4 and 5). In the early 1990s, when the first round of negotiations over the agricultural land surrounding the village failed,

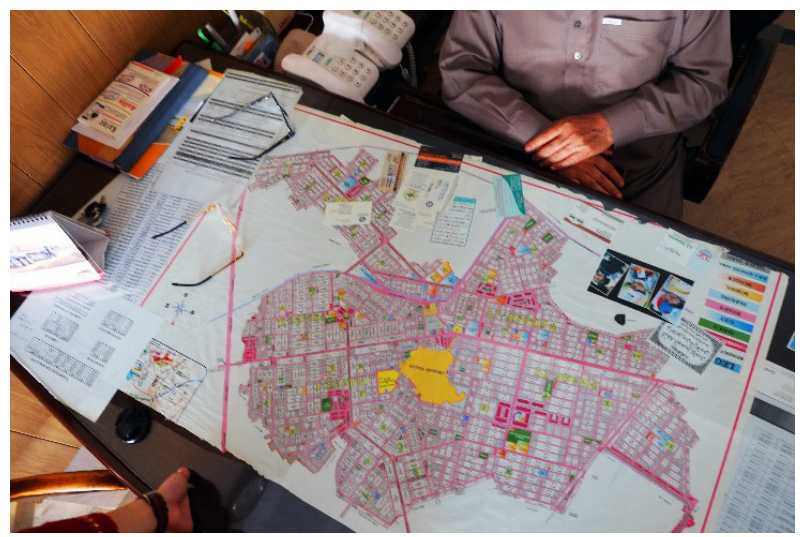

Figure 4. Picture of a real-estate map of DHAs Phases 1 to 5 surrounding Charrar Pind. the army deployed alternative mechanisms of power to have its way. Residents' accounts recalled the army's indirect use of force, instrumentalizing the police to threaten and coerce villagers into relinquishing their land, and purposively disrupting service delivery for holdouts (i.e., water provision for agriculture and electricity supply). Those villagers refusing to sell mobilized resistance on the grounds of their affective attachment to their traditional lands (interviews, March 13-14, 2016). The conflict escalated into open confrontation and violence but by the beginning of General Musharraf's military rule (1999-2008) all the agricultural land had already been acquired by the army. Unsuccessful at gaining the control of Charrar Pind's residential land however, and in order to bring a halt to the conflict with the villagers, the DHA made promises of development (e.g., to connect the settlements' sewage and drainage to the DHA's underground system). As those promises remain unfulfilled, developmental work in the left behind settlement is channelized through local governments and patronclient relations with local elites and elected Members of the Provincial or National Assemblies. The fragmentation of the urban space, as well as the vastly different quality of life between the DHA's schemes and the village remains evident (interviews/fieldnotes, March 10-16, 2016). However, Charrar Pind residents considered the increasing social networks with the beneficiaries of the DHA's schemes, as a power resource in the protracted contention over the control of the land where the village still stands (interviews, March 13, 2016).

Similar to Charrar Pind, other peri-urban villages are affected by the pace of current land transformation. As the DHA claims more land for the newest housing phases, it continues to engulf villages, further augmenting the urban land under the military's control (see Figure 6). Here, the 'gated' or 'secluded' communities are not-as one might expect-the exclusionary housing schemes, but rather the pre-existing villages. Partially fenced-off by concrete walls built by the DHA authorities, ramparts mark the limit between the territories of the original settlements and the already,

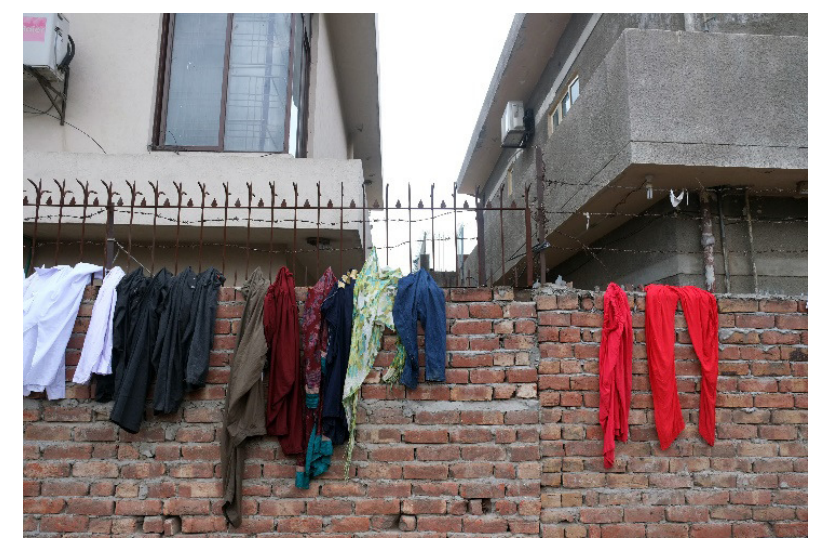

Figure 5. Wall separating DHA houses (behind) from Charrar Pind, 2015. 


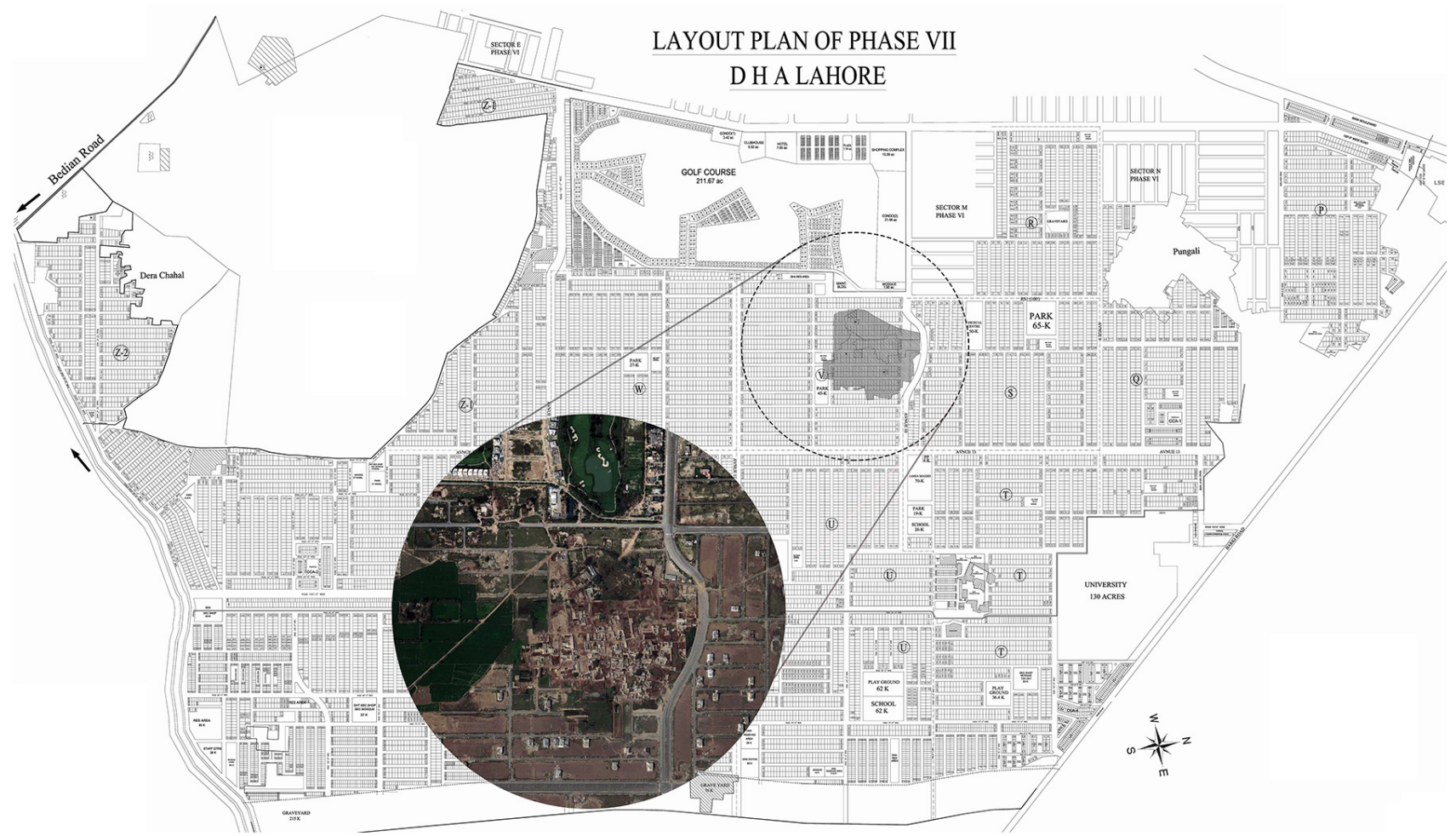

Figure 6. Peri-urban village within the planned DHA Lahore Phase 7. Source: Author based on USGS Earth-explorer satellite image and real-state layout plan from March 2013.

or soon to be, plotted housing societies (fieldnotes, October 29, 2015). Villagers' accounts described similar processes of contestation, negotiation, and resistance, and analogous mechanisms of power and pressure tactics as in Charrar Pind twenty years earlier. The same promises of development-in exchange for allowing DHA's sewage underground construction in the village communal land-remained unfulfilled. In 2015, many villagers had already sold their properties to real estate intermediaries - also referred to as "land consolidators," "gangsters," or "qabza groups" when the conflict escalated (interviews, October 30, 2015). Others resorted to organizing protests, reaching out to the media and filing court cases to ensure a protracted process, with the idea that delaying the sale of the land would ensure better returns in the future. However, with the progressive urbanization of agricultural hinterlands, villagers' sources of income have considerably diminished. Unlike in Charrar Pind, linkages with the emerging neighboring housing schemes are scarce. This is allegedly due to the fact that DHA management obstructs potential access to labor opportunities. The uncertain situation has led to a halt in upgrading work inside villages, leading to deterioration of living conditions (interviews, October 30, 2015, and December 1-3, 2015).

The conflict between the DHA and surrounded villages over the land exemplifies the dominance of the military in urban planning-in Lahore in particular and Pakistan in general. The sites and situations presented are the result of constant de/reterritorialization pro- cesses as DHA expansion affects villages' spatial boundaries (see Figures 7 and 8) and constrains the ability of local communities to access resources. The case illustrates therefore the exclusionary effect of army-led urban planning manifest in the life quality advancements in the DHA housing schemes on the one hand, and the displacement of previous residents on the other. Processes of territorialization in the DHA urban sprawl become evident in the various military checkpoints restricting entry into the DHA enclaves, as well as the fencing off of the vestigial villages. While this has been justified by the military in the name of security, it entrenches the military's control over a large part of the city and produces the socio-spatial segregation of the less well-to-do. The DHA's expansion beyond the original boundaries of the military cantonment deterritorializes in turn the jurisdictional border of civilian Lahore, undermining the mandate of civil urban planning. The DHA's territorializing processes are possible due to the subordinate position of local communities with respect to the bundles of powers at the disposal of the army. Resigned villagers make speculative calculations and mobilize (legal) rights-based and relational mechanisms just to temporarily maintain access to their land. In contrast, the DHA's power strands weave together various mechanisms of control and maintenance, such as authority exercised by force, relations to powerful actors, and modes of legitimacy based on the ideas of modernity, urbanity, and development that they claim to represent. The latter points to the often higher value 


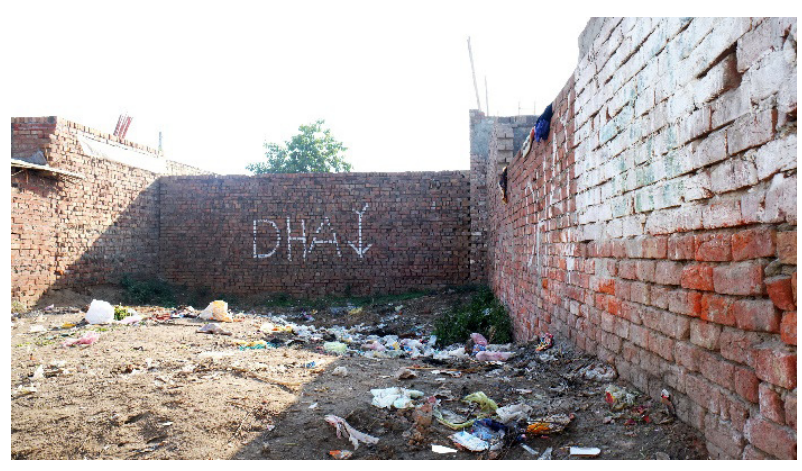

Figure 7. Plot sold to DHA in a peri-urban village, 2015.

attributed to aesthetics rather than ethics in planning interventions (Ballard, 2012; Bauman, 2005), trumping legal and ethical concerns (Rizvi, 2019).

\subsection{CASE III: LDA and the Vision for the Ravi Riverfront}

In August 2020, the LDA launched the Ravi Riverfront Urban Development Project (RRUDP) in the northern and western peripheries of the city. The RRUDP is a Rs. 5 trillion endeavor, projected to house eight million inhabitants stretching over $46 \mathrm{~km}$ and covering about $414 \mathrm{~km}^{2}$ of land-almost the size of present-day Lahore's built-up area, estimated in 2016 to be $484 \mathrm{~km}^{2}$ (Javed \& Riaz, 2020). The 2015 drafts of the RRUDP Strategic Development Plan (SDP) and Feasibility Report envisaged the displacement of at least 69 villages and five settlements of Shahdara town (in the north of Lahore district). This would affect more than 16,126 households, constituted of 96,048 people out of the about 169,000 estimated population within the project area (Meinhardt, 2015a, 2015b). For that purpose, the SDP plans to mobilize the Land Acquisition Act 1894 in combination with provisions for resettlement derived from World Bank Policy. That this level of displacement is at all possible can be best understood by observing the burgeoning powers of the LDA, permitting the development authority to bypass local government structures. That the LDA pays little attention to local bodies and provincial planning institutions is partially inherited from its predecessor, the (colonial) Lahore Improvement Trust. However, these powers have expanded even further in the post-independence period. This picture is further complicated by recent developments. Whilst the LDA (Amendment) Act 2013 gives the LDA jurisdictional powers at divisional level (including four districts of which Lahore is only one), the federal government announced to promulgate an ordinance creating a new development authority, the Ravi Riverfront Development Authority. In addition, nowhere in the LDA's successful amendments to the Lahore Master Plan 2021-in 2013, 2015, and 2016-is there reference to the RRUDP (Alam, 2020), a fact which demonstrates the disconnect between the new project and the overall planning strategy for the

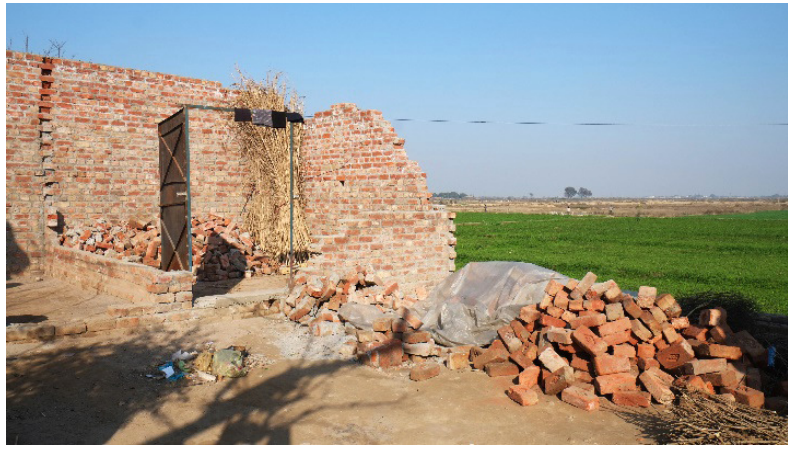

Figure 8. Deconstructed house on the edge of a village under contention with DHA, 2015.

city. Although officials have speculated about the possible establishment of the RRUDP for over a decade (interviews, October 29, 2015, and November 19, 2015), the sudden re-emergence and top-down activation of the project manifests a lack of concern for democratic participation. This was already the case back in 2015 when interviewed villagers expected to be affected by the then drafted RRUDP had no knowledge of the plans for such a radical restructuring of their lands (interviews, November 12-13, 2015).

The disconnect with reality is also illustrated in the Prime Minister of Pakistan Imran Khan's speech at the inauguration ceremony of the RRUDP on September 15, 2020 (Ary News, 2020). In the speech, he emphasized the grand scale of the "dream" and the focus on private (international) capital, while at the same time making passing reference to the necessity of a pro-poor housing approach. Under the "Naya (new) Pakistan" slogan, the Khan government proposes the RRUDP as a "new planned city," designed to address the needs of the more disadvantaged sections of society. However, beyond these references, there is little about the RRUDP that proposes it as an intervention for people at the social and economic margins. Besides the strongly voiced environmental and governance concerns about the project (Ahmed, 2020; Hasnain, 2020), in the drafted SDP there is no evidence of actual planning strategies or mechanisms enabling access to housing and services for low-income populations. The laissez-faire, market-led approach from planning institutions has only engendered speculative trends. Increasing the number of urbanizing plots and swelling the size of housing stock has so far not led to access improvements amidst the larger economic inequalities, where the wealthy have greater access to housing as a commodity rather than the poor having access to it as a service. Thus, whatever gestures are made in the SDP's blue-print approach-producing a planned city within an existing city and expecting that its quality advancements would spread into the 'defective' and 'unplanned' surroundings - are likely doomed to failure. Besides, the SDP's 'client's vision' of a 'world-class city' pursuing foreign models and imaginaries runs counter to context-appropriate urban planning. 
The emergence of the RRUDP sets several de/reterritorialization processes in motion along the River Ravi. Access mechanisms such as the (rights-based) Land Acquisition Act 1894 and the World Bank's normative Resettlement Policy (a source of international legitimacy and authority) will reshape jurisdictional boundaries and social-spatial configuration of settlements. The launch of the project alone already constrains intracommunity land transfers in areas designated for acquisition. Whereas in theory deterritorialization offers opportunities for negotiation and cooperation across previous boundaries, in practice, information asymmetries and barriers to participation territorialize the RRUDP by imposing visions and planning perspectives that are incompatible with the urban realities of contemporary Lahore. The RRUDP's top-down approach is mobilized along three main dimensions: the dominant role of the private sector, reliance on foreign investments, and the prominence of international development consultants. The latter factor exemplifies a practice that has been central to a decades-long modernization rationale that endorses the imposition of outside expertise on less developed parts of the world (Daechsel, 2018). International consultancies have often taken a defining role in planning and development projects in Pakistan, with the resultant failure in their interventions to acknowledge and address the complexity of local urban realities.

\section{Discussion}

While the RRUDP case refers to a newly launched urban development project that portends future dislocations of populations, the Bahria Town and DHA cases trace longer term contestations over peri-urban land and their evolution over time. The first case illustrated the operations of a powerful private development actor (Bahria Town) as it gained and controlled access to land for an exclusionary housing scheme. The second illustrated the expansion strategies of an ambiguous (neither public nor private) development authority under military control (DHA). In both cases, conflict and resistance preceded a gradual shift to negotiation or even cooperation as the dislocated villagers adapted to their new neighbors. In all three cases, claims to modernity, urbanity, and specific notions of development were mobilized to legitimize the displacement of pre-existing communities. In each of them, particular spatial arrangements and socio-political structures crystallized into unique access-assemblages. These access-assemblages were informed by a contrast of developmental rationalities and mechanisms of power as villagers and developers contended over the previously marginal territory. This friction and its underlying access mechanisms and bundles of powers have in turns led to processes of de/reterritorialization that determine the distribution of benefits from these massive investments in the peri-urban space. In the RRUDP case, the working out of these processes was illustrated at the level of planning, where the access-assemblage was dominated by path dependencies in governance and by deep entanglements with international development discourses, organizations, and (anticipated) flows of capital. In the cases of Bahria Town Lahore and the DHA, the scale of access-assemblages focused on the everyday practices of villagers and urban developers as they negotiated (to gain, control, or maintain) access to the contested territory and concomitant benefits.

Across the case studies, power relations crystallized as bundles of material and expressive sources of economic, social, cultural, and symbolic power. These mechanisms are the tools with which different actors shape their claims over land, housing, and services. The analysis of these power relations and access mechanisms illustrates: 1) how processes of de/re-territorialization leading to the configuration of the different accessassemblages are triggered; 2 ) the effect of these processes in shaping in and exclusionary planning (i.e., how they enabled/constrained the ability of residents in villages to benefit from urban resources); and 3) the potential of these mechanisms for producing alternative possibilities ('lines of flight').

Access-mapping highlights that de/reterritorializations processes take place as a result of the interplay between different access mechanisms. Legal and non-legal rights-based mechanisms were often interconnected. An example of this is the LDA and the DHA's use, under the premise of public purpose, of the Land Acquisition Act 1894 to undermine the property rights of pre-existing residents. As expressed in the vernacular $q a z b a$, and illustrated in the Bahria Town and DHA case studies, illegal access mechanisms encompass a wide range of strategies including force, violence, and coercion. Employed by developers and their agents, these mechanisms triggered processes of territorialization by sharpening boundaries and identities. By delimiting the territories under contention, the planning processes led by the army's housing authority and the private developer excluded local communities from potential benefits. In the case of the RRUDP, mechanisms founded in legal statute, such as the large jurisdictional area of LDA, allowed the planning institution's claims on land beyond the district boundary of Lahore and the limits heretofore marked by the River Ravi. This will trigger territorialization processes as the RRUDP delineates a new special planning area marked by defined borders, governed by its own regulations, and designed under its specific development rationalities.

Legal and non-legal rights-based mechanisms were mobilized in connection to structural or relational mechanisms. Access to technology, or particular forms of knowledge, surfaced in the case of villages threatened by DHA's expansion. Villagers mobilized the experience gained from past encroachments on rural territory to build strategies of resistance. Both against the DHA and Bahria Town Lahore, residents with a stronger affective attachment to the land territorialized/mobilized a sense 
of belonging and identity that shaped collective struggle. Experience and knowledge were also a resource shaping negotiation strategies and informing villagers' capacity to stand up to extortionate measures. It was not that peri-urban residents at risk of displacement were naive about the inevitability of their dislocation; rather these mechanisms had a speculative logic aimed at territorializing/stabilizing the conflict situation in order to secure the highest possible compensation for displacement. Negotiations were also informed by structural mechanisms such as access to capital. Villagers possessing agricultural property in the village were aware of this title as constituting not only a (legal) right-based mechanism allowing access to the contested territory during the protracted negotiation period, but also as a source of capital and bargaining power.

Although popular experience would imply similar calculations and strategies in villages falling under the territory to be subsumed by the RRUDP, villagers' land title is already prejudiced, and the ability of villagers to access markets to trade their properties constrained. In a clear process of territorialization, the launch of the RRUDP halted land transfers in anticipation of future land acquisition and the state's desire to control the payment of compensations. Access to capital will remain however a challenge for the RRUDP developers. As the project will be structured on a public-private partnership, timelines to attract the required private sector benefits may be long enough to allow landholders continued access to the territory. In contrast, unencumbered access to own capital eased Bahria Town and the DHA's access to land, particularly when compensation levels could be controlled by access and connections to institutions of authority. It was this duality that allowed urban developers to dominate the field of negotiation in spite of the villagers' putative legal protections.

Although the analysis shows prevalence of territorialization processes and exclusionary patterns of planning practices, some lines of flight emerged. In contrast with the DHA case where the army was alleged to constrain the access to livelihoods of holdouts, the porosity of the boundary created by Bahria Town created an avenue for alternative forms of cooperation between urban developers, upper-middle class residents, and dislocated villagers. This permeable boundary represents a line of flight allowing residents of the absorbed villages to benefit from labor, capital, and relations introduced into their territory. More indirectly, it shapes desires and aspirations to development that destabilize the old socio-economic marginality and serve as basis for claim-making.

\section{Conclusion}

Drawing on three ethnographic cases, this article has surveyed the in- and exclusionary role of planning within rapid land transformations at Lahore's peri-urban fringe. To this end, it developed the notion of access- assemblages, a combination of assemblage-thinking approaches and access theory. The operationalization of this concept allowed the exploration of sites and situations of conflict and claims-making that emerged amidst the rapid urbanization of Lahore's periphery, as well as the underlying dynamics, mechanisms, and power relations influencing the ability of urban actors - in particular villagers - to benefit from urban resources (i.e., access to peri-urban land, housing, and services). This revealed not only the exclusionary effects of planning and development trends but also the underlying dynamics and unequal power relations that shape these tendencies.

The analysis showed how the interplay of access mechanisms and underlying bundles of power such as property, authority, force, identity, capital, and knowledge shaped relations between actors and institutions in differentiated access-assemblages. While access mechanisms were found to be similar between the cases, they were attuned differently, producing distinct modes of legitimacy, contestation, and cooperation. Some mechanisms created possibilities for (re)territorialization (the sharpening of spatial boundaries or identities), such as the physical barriers in the private housing scheme and army developed areas, or the future new jurisdiction for the RRUDP. Other mechanisms were identified as able to trigger deterritorializing processes through which accessassemblages were destabilized and rearranged, such as the public announcement of the RRUDP or the exchanges through the relatively porous boundary of Bahria's gated community. Only the latter were considered as potentially productive lines of flight, paths for deterritorialization capable of creating alternative paths to improve access and the living conditions of local populations. All in all, the analysis clearly showed the dominance of practices of exclusion in current planning and urban development in Lahore. These, it argued, tend to territorialize and fragment the urban governance framework, and congregate and segregate populations. This calls for a critical reflection on the in- and exclusionary role of planning. There is a pressing need to reevaluate the set of values that allow planning institutions to legitimize exclusionary visions to the detriment of the larger sections of society. Instead, the article promotes a move towards supporting planning ethics that recognize the affective connections of residents with their land, as well as their desires for and claims to development (de Vries, 2007). The acknowledgement of the rhizomatic nature of access-assemblages at Lahore's urban peripherytheir inherent capacity to change and deterritorializecalls for further research to identify access-mechanisms that can productively be mobilized to shape alternative paths and spaces of opportunity. This is based on the premise that change can be productive, that 'chaos'/deterritorialization-in Deleuze and Guattari's terms - can serve as "ground zero of desire and the base for creativity" (Buchanan, 2021, p. 14). Seeking planning structures and institutions that can accommodate change and uncertainty is urgent, particularly in con- 
texts such as Lahore, where path dependent governance frameworks continually reproduce unequal patterns of socio-spatial organization.

\section{Acknowledgments}

I want to thank the editor of this thematic issue of Urban Planning and three anonymous reviewers for offering extremely useful comments. I am also grateful to Amiel Bize, Basil Ibrahim, Carsten Keller, and Ali Mohsin for proofreading the manuscript and offering detailed comments on previous versions of the article. The research was possible thanks to a grant from La Caixa Foundation in collaboration with the German Academic Exchange Service (DAAD).

\section{Conflict of Interests}

The author declares no conflict of interests.

\section{References}

Ahmed, H. (2020, July 29). Ravi riverfront project will prove to be disastrous: Experts. Daily Times. Retrieved from https://dailytimes.com.pk/647495/ ravi-riverfront-project-will-prove-to-be-disastrousexperts

Alam, A. R. (2020, July 26). Marked by folly: The Ravi Riverfront Urban Development Project raises serious questions of urban planning, environmental regulation and governance. The News on Sunday. Retrieved from https://www.thenews.com.pk/ tns/detail/691955-marked-by-folly

Allen, J., \& Cochrane, A. (2010). Assemblages of state power: Topological shifts in the organization of government and politics. Antipode, 42(5), 1071-1089.

Anjum, G. A., \& Hameed, R. (2007). The dynamics of colonization of peripheral housing schemes and policy options in case of Lahore. Pakistan Journal of Engineering and Applied Sciences, 2007(1), 24-30.

Ary News. (2020, September 15). PM Imran Khan lays foundation stone of Ravi Riverfront project. Ary News. Retrieved from https://arynews.tv/en/ pm-imran-khan-inaugurates-ravi-riverfront-urbandevelopment

Babar, F. (2019, May 24). How DHAs became the most powerful housing societies of Pakistan. The Friday Times. Retrieved from https://www. thefridaytimes.com/how-dhas-became-the-mostpowerful-housing-societies-of-pakistan

Bagaeen, S., \& Uduku, O. (Eds.). (2010). Gated communities: Social sustainability in contemporary and historical gated developments. London and Washington, DC: Earthscan.

Baker, T., \& McGuirk, P. (2017). Assemblage thinking as methodology: Commitments and practices for critical policy research. Territory, Politics, Governance, 5(4), 425-442.
Ballard, R. (2012). Geographies of development: Without the poor. Progress in Human Geography, 36(5), 563-572.

Bauman, Z. (2005). Work, consumerism and the new poor. Maidenhead: Open University Press.

Bayat, A. (2013). Life as politics: How ordinary people change the Middle East. Stanford, CA: Stanford University Press.

Bint-e-Waheed, H., \& Nadeem, O. (2019). Perception of security risk in gated and non-gated communities in Lahore, Pakistan. Journal of Housing and the Built Environment, 35, 897-915.

Buchanan, I. (2021). Assemblage theory and method: An introduction and guide. London, Oxford, New Delhi, Sydney, and New York, NY: Bloomsbury Academic.

Chatterjee, P. (2004). The politics of the governed: Reflections on popular politics in most of the world. New York, NY: Columbia University Press.

Daechsel, M. (2018). Islamabad and the politics of international development in Pakistan. New Delhi: Cambridge University Press.

Dalton, C. M. (2019). Rhizomatic data assemblages: Mapping new possibilities for urban housing data. Urban Geography, 41(8), 1090-1108.

de Vries, P. (2007). Don't compromise your desire for development! A Lacanian/Deleuzian rethinking of the anti-politics machine. Third World Quarterly, 28(1), 25-43.

DeLanda, M. (2006). New philosophy of society: Assemblage theory and social complexity. New York, NY: Continuum.

DeLanda, M. (2016). Assemblage theory. Edinburgh: Edinburgh University Press.

Deleuze, G., \& Guattari, F. (1987). A thousand plateaus: Capitalism and schizophrenia. London and Minneapolis, MN: University of Minnesota Press.

Dovey, K. (2012). Informal urbanism and complex adaptive assemblage. International Development Planning Review, 34(3), 371-390.

Ewing, K. P. (2012). Anthropology and Pakistani national imaginary. In N. Khan (Ed.), Beyond crisis: Reevaluating Pakistan (pp. 531-540). London, New Delhi, and New York, NY: Routledge.

Gilbert, A. (2002). On the mystery of capital and the myths of Hernando de Soto: What difference does legal title make? International Development Planning Review, 24(1), 1-20.

Gul, A., Nawaz, M., Basheer, M. A., Tariq, F., \& Shah, S. A. R. (2018). Built houses as a tool to control residential land speculation: A case study of Bahria Town, Lahore. Habitat International, 71, 81-87.

Hameed, R., \& Nadeem, O. (2008). Challenges of implementing urban master plans: The Lahore experience. World Academy of Science, Engineering and Technology, 17, 335-342.

Harvey, D. (2004). The "new imperialism": Accumulation by dispossession. Actuel Marx, 35(1), 71-90.

Hasnain, K. (2020, July 27). Civil society rejects Ravi river- 
front project. Dawn. Retrieved from https://www. dawn.com/news/1571275

Hull, M. (2012). Uncivil politics and the appropriation of planning in Islamabad. In N. Khan (Ed.), Beyond crisis: Re-evaluating Pakistan (pp. 452-481). London, New Delhi, and New York, NY: Routledge.

Javed, N., \& Riaz, S. (2020). Issues in urban planning and policy: The case study of Lahore, Pakistan. In B. Dahiya \& A. Das (Eds.), New urban agenda in Asia-Pacific: Governance for sustainable and inclusive cities (pp. 117-162). Singapore: Springer.

Khan, N. (2012). Mosque construction or the violence of the ordinary. In N. Khan (Ed.), Beyond crisis: Reevaluating Pakistan (pp. 482-520). London, New Delhi, and New York, NY: Routledge.

Khan, S. R., Akhtar, A. S., \& Bodla, S. (2014). The military and denied development in the Pakistani Punjab: An eroding social consensus. London and New York, NY: Anthem Press.

Kusenbach, M. (2003). Street phenomenology: The goalong as ethnographic research tool. Ethnography, 4(3), 455-485.

Landman, K. (2004). Gated communities in South Africa: The challenge for spatial planning and land use management. Town Planning Review, 75(2), 151-173.

Levien, M. (2015). From primitive accumulation to regimes of dispossession. Economic and Political Weekly, 50(22), 351-394.

$\mathrm{Li}, \mathrm{T}$. M. (2007). The will to improve: Governmentality, development, and the practice of politics. Durham and London: Duke University Press.

Mallick, A. (2018). Urban space and (the limits of) middle class hegemony in Pakistan. Urban Geography, 39(7), 1113-1120.

Martin, N. (2019). Politics, capital, and land grabs in Punjab, India. In B. Harriss-White \& L. Michelutti (Eds.), The wild East: Criminal political economies in South Asia (pp. 240-261). London: UCL Press.

McFarlane, C. (2009). Translocal assemblages: Space, power and social movements. Geoforum, 40(4), 561-567.

Meinhardt. (2015a). Ravi riverfront urban development project, Strategic development plan, Final feasibility report (Task 2.1 Volume 1/10, March 2015). Meinhardt: Singapore.

Meinhardt. (2015b). Ravi riverfront urban development project, Draft of the feasibility report, Resettlement planning (RP) document and Resettlement policy framework (RPF). Meinhardt: Singapore.

Nawaz, S. (2008). Crossed swords: Pakistan, its army, and the wars within. Karachi: Oxford University Press.

Nygren, A., \& Quesada, F. (2020). Imagining cities of inclusion: Formulating spaces of justice. Urban Planning, 5(3), 200-205.

Peluso, N. L., \& Ribot, J. (2020). Postscript: A theory of access revisited. Society \& Natural Resources, 33(2), 300-306.

Ribot, J. C., \& Peluso, N. L. (2003). A theory of access. Rural Sociology, 68(2), 153-181.

Rizvi, M. A. (2019). The ethics of staying: Social movements and land rights politics in Pakistan. Stanford, CA: Stanford University Press.

Roy, A. (2011). Slumdog cities: Rethinking subaltern urbanism. International Journal of Urban and Regional Research, 35(2), 223-238.

Russell, B., Pusey, A., \& Chatterton, P. (2011). What can an assemblage do? Seven propositions for a more strategic and politicized assemblage thinking. City, 15(5), 577-583.

Siddiqa, A. (2007). Military Inc.: Inside Pakistan's military economy. Karachi: Oxford University Press.

Sikor, T., \& Lund, C. (2009). Access and property: A question of power and authority. Development and Change, 40(1), 1-22.

Syed, N. A. (2019, August 7). A small village in Bahria fights for its life. Dawn. Retrieved from https://www. dawn.com/news/1498462

Zaman, F., \& Syed, A. N. (2016, April 18). Bahria Town Karachi: Greed unlimited. Dawn. Retrieved from http://www.dawn.com/news/1252809

Zaman, K.-U., \& Baloch, A. A. (2011). Urbanization of arable land in Lahore City in Pakistan: A case-study. Canadian Social Science, 7(4), 58-66.

\section{About the Author}

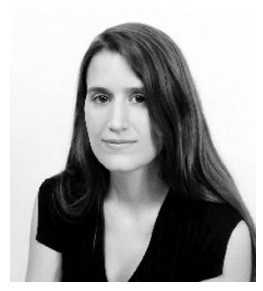

Helena Cermeño is an Architect and Urban Planner, Lecturer, and Research Fellow at the Department of Urban Sociology at the University of Kassel, and Junior Researcher at the Centre for Development Research (ZEF) at the University of Bonn, Germany. Her research on India and Pakistan focuses on urban governance and conflicts related to the politics of housing and service provision. 